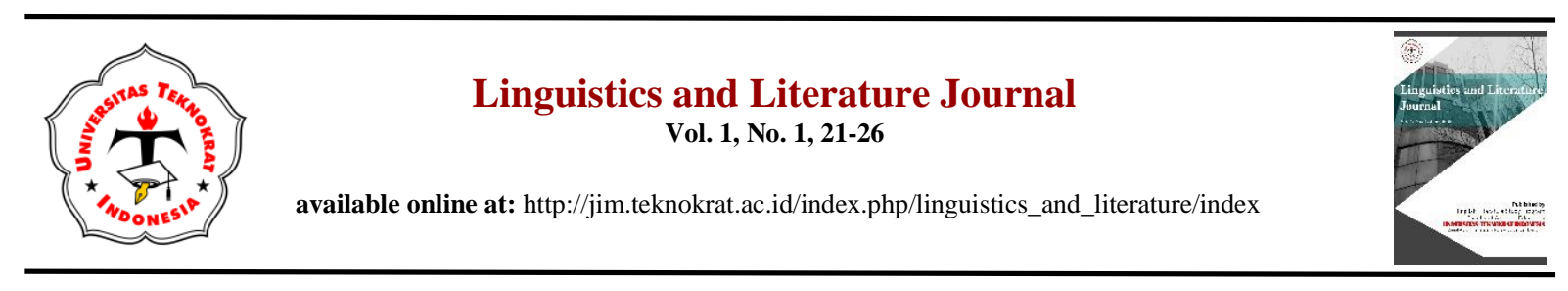

\title{
CONTRASTIVE ANALYSIS OF ENGLISH AND INDONESIAN IDIOMS OF HUMAN BODY
}

\author{
Cindy Adelina ${ }^{1}$, Suprayogi ${ }^{2}$ \\ Universitas Teknokrat Indonesia ${ }^{1,2}$ \\ cindyadelina4@gmail.com¹, suprayogi@teknokrat.ac.id ${ }^{2}$
}

Received: (April 2020)

Accepted: (May 2020)

Published: (June 2020 )

\begin{abstract}
This research analyzes English Idioms which are equivalent in Indonesian Idioms especially idioms in relation to human body. This research is conducted due to limited research on contrastive analysis in both languages in the field of semantics. The method used in this research is descriptive qualitative method. The data in this research are idioms in English which have an equivalent in Indonesian idioms and vice versa taken from dictionary of idioms and websites discussing idioms in both languages. Data are analyzed under the framework of idiom classification by Fernando (1996) and types of contrastive analysis by Lado (1957). Based on the analysis that has been done, it can be concluded that mostly the equivalence of English and Indonesian idioms are in the form of pure idioms. In the level of contrastive analysis, the idioms are categorized into three. The first is idioms in Indonesian and English which have similar meanings and similar forms of expressions. The second is idioms in Indonesian and English which have different meanings but similar forms of expressions. The third is idioms in Indonesian and English which have similar meanings but different forms of expressions. The causes of similarities between the two idioms between English and Indonesian is cultural factors between English and Indonesian in terms of percieving human body.
\end{abstract}

Keywords: contrastive analysis, English Idiom, Indonesian Idiom, human body.

\section{INTRODUCTION}

One universal element of human culture is language. Humans create languages to be able to communicate with each other. According to Kridalaksana (1993: 21) "Language is an arbitrary sound symbol system, which is used by members of a community to work together, interact, and identify themselves". Changing of language also shows society's hierarchy (Amelia, 2016). These show that language is very important for humans as social beings in daily activities, such as communicating with others. However, in everyday conversation, to communicate across culture, it is not enough to only have common knowledge of two or more languages. A variation in native language and foreign language is needed to give additional nuances in communication. One of the variation is the idiom. Thyab (2016) emphasizes the importance of understanding idioms to communicate in English as a part of language competence. When someone could master idioms of two languages, it is assumed that communication will be more successful.

One of the characteristics of language is unique. This means, there are some features in certain language that can not be seen in other languages (Kentjono, 1990). Cruse (1986: 37) states that "Idiom is an expression whose meaning cannot be accounted for as a compositional function of the meanings when they are not parts of idioms". That means even though people understand every single word, it will not be that easy to catch what exactly the sentence means. A person cannot translate it directly into their native language because expressions in foreign languages can have different meanings which cause misunderstanding. Furthermore, a person can express matters or circumstances with idioms in his native language well, but not so with foreign languages.

It is the interest of this research to see idioms in English and Indonesian since English becomes foreign language in Indonesia and is taught in education institution from primary until tertiary education. Furthermore, it is assumed that Indonesian language is mastered and used by all Indonesian citizen (Qodriani, 2012). In fact, English and Indonesian are not cognate languages because they have their own rules, or both languages are from different origins. The study of idioms in both language is also important. As a primary investigation, some samples of idioms of two languages were conducted. Indonesian has the idiom tangankanan (right hand) and English also has it exactly using phrase right hand. Both of them share the same idiomatic meaning as confidant or the most trusted person. 
Another example, English has idiom lose face, and Indonesia has hilangmuka (lose face) where both idioms also have the same idiomatic meaning, that is shame.

The researchers believe that there are more idioms that can be found in both languages, especially on human body. Idioms related to human body in both languages raised as the topic of this research. It is because there are limited researches related to contrastive analysis of idioms using members of human body in English and Indonesian. Human body is used as the element of idioms because human body is the closest thing with human that can be described and easy to understand by the readers. Some researches on comparison on idioms in two languages are Li (2010) that compared English and Chinese Idioms from the perspective of conceptual metaphor of happiness, Fatmawati (2011) analyzed Comparison American and British Idioms and Sari and Jumanto (2018) that analyzed Indonesian Translation of the novel The Girl on the Train by Paula Hawkins.

This research is approached from the perspective of semantics and contrastive analysis. Contrastive Analysis is one of the methods that can be used for helping people who learn other language in finding some differences and similarities between source language and target language that usually led to some difficulties in learning process encountered by the learner. According to Fisiak (1981) "Contrastive Analysis is a sub discipline of linguistics that deals with the comparison of two or more languages in order to determine both the differences and similarities that hold between them. It is like what Suprayogi (2018) has done in comparing lexical feature of Javanese, Lampung, Komering, Sundanese and Komering in Lampung province. Furthermore, Gulö (2017) has done in contrasting predicates between English and Indonesian, and Afrianto (2017) which study the relational clause in Lampung language and Indonesia. The object of study from contrastive analysis are elements and linguistic systems as well as cultural background of the first language (L1) and second language (L2). Thus, the question that is addressed in this research is "what are the similarities between English and Indonesian idiom of human body?" within the scope of discussion on the body parts of head, hand, heart, and leg.

\section{METHOD}

This research employed qualitative descriptive method. This method was employed because the research data was described to see the uniqueness of each datum, then analyzed and interpreted objectively. This method also emphasized in the aspects of meaning and experience (Afrianto, 2016). Qualitative descriptive method is a method that researchers can use to analyze by searching for facts with the right interpretation and to find the similarities and differences between Indonesian and English idioms. In other words, the results of the analysis are in form of words (Kuswoyo \& Susardi, 2016). Data in this research are idioms in English and Indonesian obtained from Kamus Lengkap Idiom Inggris-Indonesia by Suwardi Salim (2017) and English website on idioms.

English idioms and Indonesian idioms were selected from the dictionary and websites and put into category of human body, which are head, hand, heart, and leg. Then, those idioms are matched based on the similarity or connection based on the theory of contrastive analysis by Lado. According to Lado (1957: 82), "in finding similarities and differences between the two languages, there will be seven types of contrastive analysis: 1) Similar forms and meanings, 2) Similar form different meanings, 2) Similar meanings, different forms, 3) Different forms and meanings, 4) Different construction, 5) The same primary meaning, 6) different connotation. 7) The same meaning, but has restrictions regarding the distribution of geographic areas". From the seven types above, the researchers will discuss in this study only the first three types, namely similar forms and meanings, similar form but different meanings, and similar meanings but different forms. The researchers chose these three types because they relate to the meanings that can be applied in the comparative analysis of idioms, and also the limitations in this study. The next step is identifying the types of idiom according to idioms type by Fernando (1996: 35) that are "pure idioms, semi idioms, and literal idioms". The last one is the analysis and interpretation of the findings. The finding of this research will not focus on pattern or generalization, but on presenting the knowledge for the readers (Stake, 2010 in Afrianto 2019), thus it will show the uniqueness of data findings.

\section{FINDINGS AND DISCUSSION}

In the research of human body idioms comparison, there were 30 English and Indonesian idioms that were matched. The idioms were reviewed from their literal and idiomatic meanings. Furthermore, it is categorized into three types of idioms, whether including pure idioms, semi idioms, or literal idioms based on the theory used in this research

\section{Comparison type I}

Comparison type I in this context is idioms derived from the element of human body parts in Indonesian and English which have similar meanings and similar forms of expressions. The following are the idioms in English that 
Linguistics and Literature Journal, Vol. 1, No. 1, 21-27

using the element of human body and their equivalents in Indonesian that have similar word choices and similar meaning.

Table 1. Idioms in Comparison Type I

\begin{tabular}{|c|c|c|l|}
\hline English Idiom & Indonesian Idiom & Meaning & Type \\
\hline Broken heart & Patah hati & $\begin{array}{c}\text { Feeling sad because } \\
\text { of break up }\end{array}$ & Pure idiom \\
\hline Big mouth & Mulutbesar & Bragging & Pure idiom \\
\hline Lose face & Hilangmuka & Shame & Pure idiom \\
\hline Blood sucker & Penghisap darah & Money lender & Pure idiom \\
\hline
\end{tabular}

The idiom broken heart in English idiom matches with patahhati in Indonesian idiom, both broken heart and patahhati have similar form and meaning. The explanation of the meaning between two idioms above can be seen in sentences are as follows:

1. Two years ago I got broken heart because my boyfriend got married other woman.

Translation: Dua tahun lalu saya patah hati karena pacar saya menikah dengan wanita lain.

The example means that she feels sad because her ex-boyfriend married woman. Broken heart idiom in English or patahhati in Indonesian come into pure idiom type. Pure idiom is a kind of conventionalized no-literal multiword expression or the meaning of idioms cannot be decoded by combining the meaning of their individual parts. The idiom broken heart in English or patahhati in Indonesian has a literal meaning as heart which is broken. Both broken heart and patahhati have a literal meaning which has no relation to its idiomatic meaning as feeling sad because of breaking up in a relationship. In the example, it can be seen the similarity in the choice of words and meanings in English and Indonesian idioms. This is because of the similar perception of the heart between this two culture. In Indonesian culture and English culture the heart symbolizes a person's feelings. Whereas the word broken usually indicates a feeling of hurt, so to put forward a feeling of a heart that is hurt in English using broken heart idioms and in Indonesian using patahhati idioms.

The idiom big mouth in English idiom matches with mulutbesar in Indonesian idiom as both big mouth and mulutbesar have similar form and meaning. Big mouth idiom in English or mulutbesar in Indonesian come into pure idiom type. The idiom big mouth in English or mulutbesar in Indonesian has a literal meaning as mouth which has big in size. Both big mouth and mulutbesar have a literal meaning which has no relation to its idiomatic meaning as someone who likes to brag to somebody else.

2. He is a big mouth. He always boasts himself to somebody else.

Translation: Dia adalah orang yang bermulutbesar. Dia selalu menyombongkan dirinya kepada orang lain.

This relates to perceptions or similarities between English culture and Indonesian culture. The perspective on the function of the mouth that makes these perceptions the same. Basically all humans have the same mouth and function to eat, beside that the other function of mouth is to talk. The big words usually have a negative connotation so that the idioms of big mouth and mulut besar have a negative meaning which is talking a lot with nonsense. The idiom lose face in English idiom matches with hilangmuka in Indonesian idiom, bothlose faceand hilangmuka have similar form and meaning. The explanation of the meaning between these two idioms above are as follows:

3. Things will go better if you can explain to him where he was wrong without making him lose face. Translation: Sетиa akan berjalan baik jika kamu menjelaskan kepadanya dimana kesalahannya tanpa membuatnya kehilangan muka.

Lose face idiom in English or hilangmuka in Indonesian come into pure idiom type. The idiom lose face in English or hilang Muka in Indonesian has a literal meaning as face which is lost or gone. Both lose face and hilangmuka have a literal meaning which has no relation to its idiomatic meaning as feeling of shame. The context of the use of these idiom is usually found at an event where someone made a mistake or made something embarrassing, she/he doesn't want to be seen by someone else so that he or she has lost their face in front of the crowd.

The idiom blood sucker in English idiom matches with penghisapdarah (lintahdarat) in Indonesian idiom, both blood sucker and penghisapdarah have similar form and meaning. The explanation of the meaning between two idioms above, as follows: 
4. I heard your uncle is a blood sucker. Is it true?

5. Translation: Saya dengar pamanmu adalah seorang penghisap darah. Apakah benar?

Blood sucker idiom in English or penghisapdarah in Indonesian come into pure idiom type. The idiom blood sucker in English or penghisapdarah in Indonesian has a literal meaning as something that can suck the blood. Both blood sucker and penghisapdarah has a literal meaning which has no relation to its idiomatic meaning as moneylender. The word suck usually has a negative meaning which is 'doing something bad'. Besides that blood is an important part of the body for humans, without blood human cannot live. If someone's blood is taken over and over, he/she will die. The meaning of moneylender is a person who takes advantage over the suffering of others by lending the money usually with high tax and not negotiable. That means that the person is doing something that is not good.

\section{Comparison type II}

Comparison type II is idioms derived from the element of human body parts in Indonesian and English which have different meanings but similar forms of expressions. The following are the idioms in English that are use the element of human body and their equivalents in Indonesian that have similar word choices but have different meaning.

Table 2. Idioms in Comparison Type II

\begin{tabular}{|l|l|l|l|l|l|}
\hline \multicolumn{1}{|c|}{$\begin{array}{c}\text { English } \\
\text { Idiom }\end{array}$} & \multicolumn{1}{|c|}{ Meaning } & \multicolumn{1}{|c|}{ Type } & \multicolumn{1}{|c|}{$\begin{array}{c}\text { Indonesian } \\
\text { idiom }\end{array}$} & \multicolumn{1}{|c|}{ Meaning } & \multicolumn{1}{|c|}{ Type } \\
\hline Big hearted & Kind person & Pure idiom & $\begin{array}{l}\text { Besarhati } \\
\text { (big heart) }\end{array}$ & $\begin{array}{l}\text { Proud, } \\
\text { happy }\end{array}$ & $\begin{array}{l}\text { Pure } \\
\text { idiom }\end{array}$ \\
\hline Longhand & Handwriting & Pure idiom & $\begin{array}{l}\text { Panjangtangan } \\
\text { (long hand) }\end{array}$ & $\begin{array}{l}\text { Steal } \\
\text { Pure } \\
\text { idiom }\end{array}$ \\
\hline Shake a leg & In a hurry & Pure idiom & $\begin{array}{l}\text { Menggoyang } \\
\text { kaki (shake } \\
\text { feet/leg) }\end{array}$ & $\begin{array}{l}\text { having fun } \\
\text { despite } \\
\text { being } \\
\text { unemployed }\end{array}$ & $\begin{array}{l}\text { Pure } \\
\text { idiom }\end{array}$ \\
\hline Thick skinned & $\begin{array}{l}\text { Have no } \\
\text { shame }\end{array}$ & Pure idiom & $\begin{array}{l}\text { Kulittebal } \\
\text { (thick skinned) }\end{array}$ & $\begin{array}{l}\text { indifferent } \\
\text { or } \\
\text { insensitive }\end{array}$ & $\begin{array}{l}\text { Pure } \\
\text { idiom }\end{array}$ \\
\hline
\end{tabular}

The idiom big hearted in English idiom matches with besarhati in Indonesian idiom, but big hearted and besarhati have different meaning, although both have the same form. Big hearted idiom in English or besarhati in Indonesian come into pure idiom type. The idiom big hearted in English or besarhati in Indonesian has a literal meaning as heart that is big. Idiomatically, big hearted means kind person and besarhati as feeling of proud or happy. In both culture, the heart is usually used to express a person's feelings or traits. The word Big is not always have a positive connotation, for example besarkepala (big head) has negative connotations as an arrogant person. But, it is different with the heart, heart usually often has a positive connotation so that the larger the size of the heart, the better kindness. Whereas in the Indonesian idiom besarhati (big heart) have positive meaning but not the same. It means a feel of proud or happy because Indonesian people if they have something big or many they will feel proud.

The idiom longhand in English idiom matches with tanganpanjang in Indonesian idiom, but longhandand tanganpanjang have different meaning, although both have the similar form. Longhand idiom in English or panjangtangan in Indonesian come into pure idiom type. Longhand idiom in English consists of two words namely long and hand. In Indonesian panjang is the English word of long and tangan is the English word for hand. Even though they have the same choice of words, they both has different meaning. In English longhand has a meaning as handwriting, while the idiom panjangtangan in Indonesian has a meaning as thief or someone who steals. This is because if someone has a long hand they can easily take something even far, therefore the idiom panjangtangan in Indonesian society is assumed to be someone who likes to steal.

The idiom shake a leg in English idiom matches with menggoyang kaki in Indonesian idiom,but shake a legand menggoyang kaki have different meaning, although both have the similar form. Shake a leg idiom in English or menggoyang kaki in Indonesian come into pure idiom type. In the English idiom shake a leg consists of the word shake, $a$ and leg which mean moving the leg meanwhile in Indonesian menggoyang means shake, and kaki means leg or feet. However, idiomatically, shake a leg means in a hurry and menggoyang kaki means having fun despite being unemployed. Leg is associated with movement of body to other place using feet, so leg is used to describe that feeling. Whereas, in Indonesian menggoyang kaki means having fun or being relaxed in their spare time. Usually, they shake their legs while sitting. 
The idiom thick skinned in English idiom matches with kulittebal in Indonesian idiom, but thick skinnedand kulittebal have different meaning, although both have the similar form. The idiom thick skinned in English or kulittebal in Indonesian has literal meaning as skin which is thick in size. The word thick is the English of tebal in Indonesian, and the word skin is the English of kulit. However, in English thick skinned means someone who has no shame and kulittebal as someone who is insensitive. Thick skinned has the meaning someone who has no shame and this is because thick skin is like the skin on feet. When pinched, it is not hurt or feels as painful as other parts of the skin due to different levels of thickness. While kulittebal means insensitive because thick skin has a low level of sensitivity, therefore this idiom describes someone who is not care and aware of the situation surrounding or someone's feeling. Actually, both of idioms has slight similarity in meaning. Both shows that someone still feels fine to do something like nothing happens.

\section{Comparison type III}

Comparison type III is idioms derived from the element of human body parts in Indonesian and English which have similar meanings but different forms of expressions. The following are idioms in English that are use the element of human body and their equivalents in Indonesian that have different word choices but have the same meaning.

Table 3. Idioms in Comparison Type III

\begin{tabular}{|l|l|l|l|l|}
\hline No. & \multicolumn{1}{|c|}{$\begin{array}{c}\text { English } \\
\text { idiom }\end{array}$} & \multicolumn{1}{|c|}{$\begin{array}{c}\text { Indonesian } \\
\text { idiom }\end{array}$} & \multicolumn{1}{c|}{ Typeaning } \\
\hline 1 & Light fingered & $\begin{array}{l}\text { Panjangtangan (long } \\
\text { hand) }\end{array}$ & Steal & Pure idiom \\
\hline 2 & Seal the lips & $\begin{array}{l}\text { Tutupmulut (close the } \\
\text { mouth) }\end{array}$ & Keep a secret & Pure idiom \\
\hline 3 & $\begin{array}{l}\text { Two tongue } \\
\text { (Dictionary }\end{array}$ & $\begin{array}{l}\text { Lidahular (snake's tongue) } \\
\text { (Dictionary }\end{array}$ & $\begin{array}{l}\text { Kepaladingin } \\
\text { headed) }\end{array}$ & Pure idiom \\
\hline 4 & \multicolumn{1}{|c|}{ Cald- } & Pure idiom \\
\hline
\end{tabular}

The idiom light fingered in English idiom matches with panjangtangan in Indonesian idiom. Light fingered idioms in English or panjangtangan in Indonesian come into pure idiom type. English idiom uses the word fingered' and light in light fingered which is literally means the fingers that are light or not heavy. However, idiomatically, this means someone who like to steal. Meanwhile, in Indonesia, someone who like to steal is expressed using idiom panjang tangan. The idioms use the word tangan for hand and panjang for long. Conceptually, the relation between fingers or hands is actually close due to different markedness. Light in English has association with something that is not heavy and is not hard, and finger is the part of the body to take somethig, light finger expresses that people will be easy to take something that are not theirs. However, the easiness is expressed using the phrase panjang tangan.

The idiom seal the lips in English idiom matches with tutupmulut in Indonesian idiom. Seal the lips idioms in English or tutupmulut in Indonesian come into pure idiom type. The idiom seal the lips in English or tutupmulut in Indonesian has a literal meaning as someone close his or her mouth that is not related to its idiomatic meaning as keep someone's secret. This idiom describes the nature of someone who promise to keep something a secret, they will say my lips are sealed, it is something someone say to let someone know that he or she will not tell anyone else what they have just told. English idiom uses the word seal which means to seal or attach something with glue or isolated and the word lips which means part of mouth. The equivalent in Indonesian is the word close or menutup andmouth or mulut. The English idiom uses the word seal which means to seal or menyegel because Westerners and Indonesians have different perspectives to express an expression.

The idiom two tonguedin English idiom matches with lidahular in Indonesian idiom. Two tongue idioms in English or lidahular in Indonesian come into pure idiom type. The idiom two tongue in English or lidahular in Indonesian has a idiomatic meaning as someone who has double tounge that is not related to its idiomatic meaning as someone who dishonest or someone who talk differently and cannot be trusted. This idiom describes the nature of someone who talks differently to one and another and cannot be trusted. It is likened to the phrase two tongue in English or lidahular in Indonesian. Both two tongue and lidahular have a literal meaning which has no relation to dishonest. Idiom Indonesian uses the word ular (snake) and lidah (tongue). Snake has a branching tongue and snakes are animals that have a negative connotation both in Indonesian and English people, because snake is a venomous animal that has poisons so that it is poisonous to human. Although it has the same view of snakes, but because of the culture of English and Indonesian is different so that the way of expression is also different.

The idiom level-headed in English idiom matches with kepaladingin in Indonesian idiom. Level-headed idioms in English or kepaladingin in Indonesian come into pure idiom type. The idiom level-headed in English or kepaladingin 
in Indonesian has a literal meaning as someone who has a cold head that is not related to its idiomatic meaning as someone who has a calm mind. This idiom describes the nature of someone who face the problems with a calm mind or thinking calmly, so that the problem solved better and there is no other new problem raised. It is something someone say to describe a person who thinking calmly to solve the problems. It is likened to the phrase level-headed in English or kepaladingin in Indonesian. Both Indonesian and English idioms use the word head because it is the place for the brain which has the function to think. Indonesian use the word dingin (cold) to associate it with something that is not in high tempered or emotional. Kepala dingin (cold head) also associates with thinking about the problem clearly.

\section{CONCLUSION}

The idioms of human body in English and Indonesian show some connection. There are some aspects of worldview that are similar especially in the concept of mouth in relation to talk or discussion, head in relation to thinking, hand in relation to taking something and heart in relation to feeling. The idioms classified in comparison type II are mostly idiom with totally different meaning. It shows different persepective on how English people perceived certain human body in relation to their social practices. Furthermore, mostly the idioms are classified as pure idiom; However, there are some partial relation or in idioms in both language such as finger and hand, leg and foot, lips and mouth.

Knowing that some idioms in English have equivalences in Indonesian idioms, this research may have pedagogical implication. Studying semantics especially idioms for linguistics students as well as studying English langauge EFL learners will be contextualized and practical since they experience the concept in their mother language. However, since this research is still limited to some parts of human body, the next research has extensive area in comparing more human body idioms completed with richer source of data.

\section{REFERENCES}

Afrianto \& Inayati, Anisa. (2016). Existential process in Harry Potter and the Chamber of Secret: A systematic functional linguistic study. Teknosastik: Jurnal Bahasa dan Sastra, 14(1), 26-31.

Afrianto. (2017). Comparing relational clause in English and Lampungnese. Paper presented in $7^{\text {th }}$ Annual Conference of Linguistics SETALI 2019. Iwa Lukmana \& Eri Kurniawan (eds), Universitas Pendidikan Indonesia, Bandung, Indonesia, 28-34.

Afrianto. (2019). English and Lampungnese relational process. Lingua: Jurnal Bahasa dan Sastra, 19(2). 118-129.

Amelia, Dina. (2016). Indonesian literature's position in world literature. Teknosastik: Jurnal Bahasa dan Sastra, 14(2), 1-5.

Cruse, D. A. (1986). Lexical Semantics. Cambridge: Cambridge University Press.

Fatmawati, Nanik. (2011). A Comparison Analysis of American and British Idioms. Universitas Islam Negri Syarif Hidayatullah, Jakarta.

Fernando, C. (1996). Idioms and Idiomaticity. Oxford University Press. Oxford.

Fisiak, J. (1981). Contrastive Linguistics and the Language Teacher. Oxford: Pergamon Press.

Gulö, Ingatan. (2017). Predicates in Indonesian and English simple sentences. Teknosastik: Jurnal Bahasa dan Sastra, 15(2), 7680.

Kentjono, D. (1990). Dasar-dasar Linguistik Umum. Fakultas Sastra Universitas Indonesia.

Kuswoyo, Heri \& Susardi. (2016). Thematic progression in EFL students' academic writings: A systematic functional grammar Ssudy. Teknosastik: Jurnal Bahasa dan Sastra, 14(2), 39-45.

Lado, R. (1957). Linguistics Across Cultures. University of Michigan Press.

Li, X. (2010). A comparative analysis of English and Chinese idioms: from the perspective of conceptual metaphor of "Happiness". Journal of Language Teaching and Research, 1(4), 473-476.

Qodriani, L. Ulsi. (2012). The use of phatic particle 'geh' in Lampungnese's Indonesian language. Teknosastik: Jurnal Bahasa dan Sastra, 10(1), 34-38.

Salim, S. (2017). Kamus Lengkap Idiom Inggris-Indonesia.Jakarta: Pustaka Gama.

Sari, D.N. \& Jumanto, J. (2018). A Contrastive Analysis and its Indonesian Translation in the novel The Girl on the Train by Paula Hawkin E-Structure, $1(1), 88-100$ 
Linguistics and Literature Journal, Vol. 1, No. 1, 21-27

Suprayogi. (2018). Geographical language variation in Pringsewu regency of Lampung province. Papers from The Fourth International Conference of Geolinguistics 2018. Universitas Indonesia.

Thyab, R.A. (2016). The necessity of idiomatic expressions to English language learners. International Journal of English and Literature, 7(7), 106-111. 